\title{
INFLUENCE OF THE WHEELS ON THE AUTOMOBILE DYNAMICS
}

The analysis of the vehicle dynamics with various types of wheels $(R 13, R 14, R 15)$ in two shifting modes and at the driving on a horizontal plane, at downhill-and uphill-driving as well as with different vehicle total mass is described in this paper.

\section{Introduction}

Contemporary automotive producers allow to equip each of their cars with disks and pneumatics of various sizes. In general, there are several combinations available among them. The influence analysis of some disks and pneumatics combinations on chosen dynamical characteristics of the automobile starting up is made in the paper. The vehicle Škoda Felicia 1.3MPI $40 \mathrm{~kW}$ was chosen for the solution of the problem. There were compared combinations of these disks and pneumatics: 165/70 R13, 155/80 R14, 195/65 R15. Especially, rotational speed of the engine was monitored in detail from a large number of parameters.

\section{Analysis of the car wheels type influence}

A numerical simulation with utilization of the program DYNAST [1] solved the problem of the vehicle starting up. The mathematical model [2] consists of a motion equation and supplementary equations defining resistances against movement and functional dependences of important quantities [3]. The speed characteristic of the considered engine $1.3 \mathrm{MPI} 40 \mathrm{~kW}$ is in Fig. 1.

Analyses of the running up dynamics were made for two values of RPM at gear change - $5500 \mathrm{~min}^{-1}$ (maximum, given by the engine characteristic) and $4000 \mathrm{~min}^{-1}$ (a lower value for usual drive). Other analyses were made for various values of the road inclination - horizontal road, uprising $+10 \%\left(+5.71^{\circ}\right)$, decreasing $-10 \%\left(-5.71^{\circ}\right)$ and for various values of the total vehicle mass (standard value $1025 \mathrm{~kg}$, maximum $1420 \mathrm{~kg}$ ).

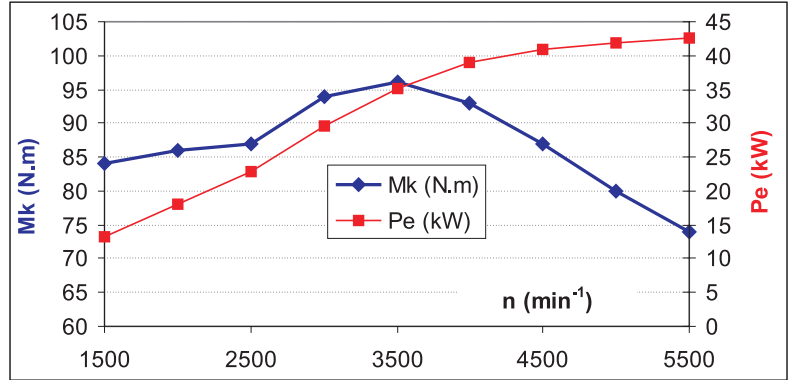

Fig. 1 Speed characteristics of the engine ŠKODA $1.3 \mathrm{MPI} / 40 \mathrm{~kW}$

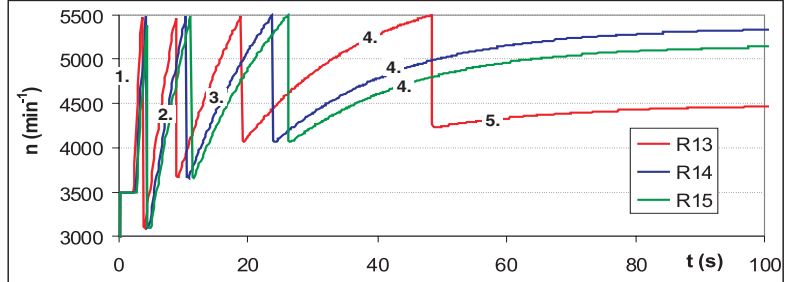

Fig. 2 Dynamic characteristics of the engine rotational speed, gear change at $5500 \mathrm{~min}^{-1}$

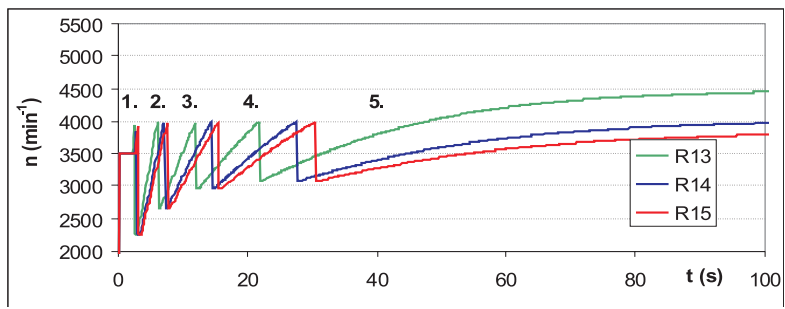

Fig. 3 Dynamic characteristics of the engine rotational speed, gear change at $4000 \mathrm{~min}^{-1}$

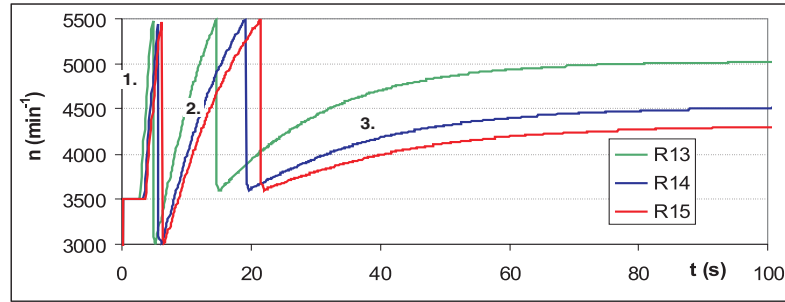

Fig. 4 Dynamic characteristics of the engine rotational speed, up rise $+5.71^{\circ}$.

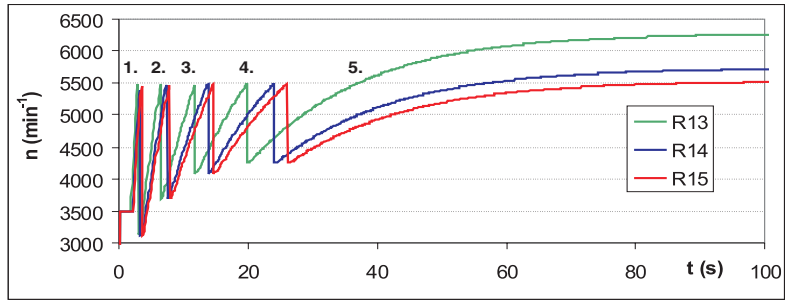

Fig. 5 Dynamic characteristics of the engine rotational speed (unlimited), decrease $-5.71^{\circ}$.

\footnotetext{
* doc. Ing. Rastislav Isteník, PhD., Ing. Dalibor Barta, Ing. Wladyslaw Mucha,

Department of Railway Vehicles, Engines and Lifting Equipment, Faculty of Mechanical Engineering, University of Žilina, Moyzesova 20, 01026 Žilina, Slovak Republic, Tel.: ++421-41- 6462660, fax: ++421-41-53016,

E-mail: rasto_istenik@kkvmz.utc.sk, dalibor@kkvmz.utc.sk, wladyslaw_mucha@kkvmz.utc.sk
} 


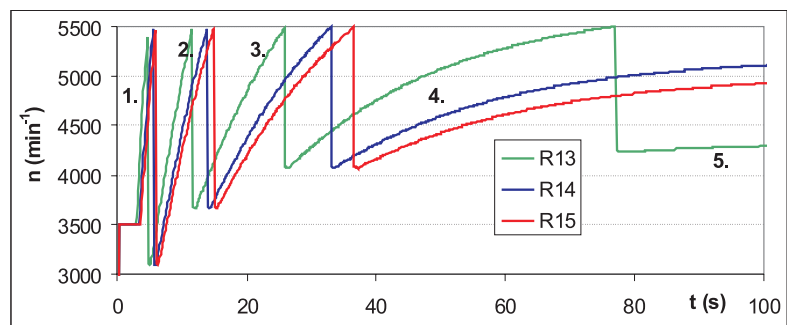

Fig. 6 Dynamic characteristics of the engine rotational speed, vehicle mass $1420 \mathrm{~kg}, 0^{\circ}$

Influence of rotational speed at the gear change

Tab. 1 (road inclination $0^{\circ}$, total vehicle mass $1025 \mathrm{~kg}$ )

\begin{tabular}{|c|c|c|c|c|}
\hline \multirow{2}{*}{$\begin{array}{c}\text { Wheel } \\
\text { type }\end{array}$} & \multicolumn{2}{|c|}{ Gear change at $5500 \mathrm{~min}^{-1}$} & \multicolumn{2}{c|}{ Gear change at $4000 \mathrm{~min}^{-1}$} \\
\cline { 2 - 5 } & $\begin{array}{c}\text { Time to } \\
100 \mathrm{~km} / \mathrm{h}\end{array}$ & $\begin{array}{c}\text { Maximal } \\
\text { velocity }\end{array}$ & $\begin{array}{c}\text { Time to } \\
100 \mathrm{~km} / \mathrm{h}\end{array}$ & $\begin{array}{c}\text { Maximal } \\
\text { velocity }\end{array}$ \\
\hline R13 & $16.215 \mathrm{~s}$ & $153.09 \mathrm{~km} \cdot \mathrm{h}^{-1}$ & $19.664 \mathrm{~s}$ & $153.08 \mathrm{~km} \cdot \mathrm{h}^{-1}$ \\
\hline R14 & $16.568 \mathrm{~s}$ & $155.11 \mathrm{~km} \cdot \mathrm{h}^{-1}$ & $20.410 \mathrm{~s}$ & $150.50 \mathrm{~km} \cdot \mathrm{h}^{-1}$ \\
\hline R15 & $16.773 \mathrm{~s}$ & $154.75 \mathrm{~km} \cdot \mathrm{h}^{-1}$ & $20.701 \mathrm{~s}$ & $148.72 \mathrm{~km} \cdot \mathrm{h}^{-1}$ \\
\hline
\end{tabular}

Influence of the road inclination - decreasing,

Tab. 2 (gear change at $5500 \mathrm{~min}^{-1}$, road inclination $-5.71^{\circ}$, total vehicle mass $1025 \mathrm{~kg}$ )

\begin{tabular}{|c|c|c|c|c|}
\hline $\begin{array}{c}\text { Wheel } \\
\text { type }\end{array}$ & \multicolumn{2}{|c|}{$\begin{array}{c}\text { Without rotational } \\
\text { speed limitation }\end{array}$} & \multicolumn{2}{c|}{$\begin{array}{c}\text { Limitation to } \\
\mathrm{n}=5500 \mathrm{~min}^{-1}\end{array}$} \\
\cline { 2 - 5 } & $\begin{array}{c}\text { Time to } \\
100 \mathrm{~km} / \mathrm{h}\end{array}$ & $\begin{array}{c}\text { Maximal } \\
\text { velocity }\end{array}$ & $\begin{array}{c}\text { Time to } \\
100 \mathrm{~km} / \mathrm{h}\end{array}$ & $\begin{array}{c}\text { Maximal } \\
\text { velocity }\end{array}$ \\
\hline R13 & $10.512 \mathrm{~s}$ & $\begin{array}{c}213.95 \mathrm{~km} \cdot \mathrm{h}^{-1} \text { at } \\
\mathrm{n}=6273.77 \mathrm{~min}^{-1}\end{array}$ & $10.517 \mathrm{~s}$ & $187.58 \mathrm{~km} \cdot \mathrm{h}^{-1}$ \\
\hline R14 & $10.639 \mathrm{~s}$ & $\begin{array}{l}214.1559 \mathrm{~km} \cdot \mathrm{h}^{-1} \text { at } \\
\mathrm{n}=5732.71 \mathrm{~min}^{-1}\end{array}$ & $10.637 \mathrm{~s}$ & $205.47 \mathrm{~km} \cdot \mathrm{h}^{-1}$ \\
\hline R15 & $10.726 \mathrm{~s}$ & $\begin{array}{c}214.0691 \mathrm{~km} \cdot \mathrm{h}^{-1} \text { at } \\
\mathrm{n}=5537.44 \mathrm{~min}^{-1}\end{array}$ & $10.727 \mathrm{~s}$ & $212.62 \mathrm{~km} \cdot \mathrm{h}^{-1}$ \\
\hline
\end{tabular}

Influence of the road inclination - uprising, Tab. 3 (gear change at $5500 \mathrm{~min}^{-1}$, road inclination $+5.71^{\circ}$, total vehicle mass $1025 \mathrm{~kg}$ )

\begin{tabular}{|c|c|c|}
\hline $\begin{array}{c}\text { Wheel } \\
\text { type }\end{array}$ & Time to $100 \mathrm{~km} / \mathrm{h}$ & Maximal velocity \\
\hline R13 & (inaccessible $100 \mathrm{~km} / \mathrm{h}$ ) & $98.85 \mathrm{~km} \cdot \mathrm{h}^{-1}$ \\
\hline R14 & (inaccessible $100 \mathrm{~km} / \mathrm{h})$ & $97.41 \mathrm{~km} \cdot \mathrm{h}^{-1}$ \\
\hline R15 & (inaccessible $100 \mathrm{~km} / \mathrm{h})$ & $96.20 \mathrm{~km} \cdot \mathrm{h}^{-1}$ \\
\hline
\end{tabular}

Influence of the total vehicle mass

(gear change at $5500 \mathrm{~min}^{-1}$, road inclination $0^{\circ}$ )

\begin{tabular}{|c|c|c|c|c|}
\hline $\begin{array}{c}\text { Wheel } \\
\text { type }\end{array}$ & \multicolumn{2}{|c|}{$\begin{array}{c}\text { Total mass } \\
\text { of the vehicle } 1025 \mathrm{~kg}\end{array}$} & \multicolumn{2}{c|}{$\begin{array}{c}\text { Total mass } \\
\text { of the vehicle } 1420 \mathrm{~kg}\end{array}$} \\
\cline { 2 - 5 } & $\begin{array}{c}\text { Time to } \\
100 \mathrm{~km} / \mathrm{h}\end{array}$ & $\begin{array}{c}\text { Maximal } \\
\text { velocity }\end{array}$ & $\begin{array}{c}\text { Time to } \\
100 \mathrm{~km} / \mathrm{h}\end{array}$ & $\begin{array}{c}\text { Maximal } \\
\text { velocity }\end{array}$ \\
\hline R13 & $16.215 \mathrm{~s}$ & $153.09 \mathrm{~km} \cdot \mathrm{h}^{-1}$ & $22.012 \mathrm{~s}$ & $147.88 \mathrm{~km} \cdot \mathrm{h}^{-1}$ \\
\hline R14 & $16.568 \mathrm{~s}$ & $155.11 \mathrm{~km} \cdot \mathrm{h}^{-1}$ & $22.537 \mathrm{~s}$ & $150.32 \mathrm{~km} \cdot \mathrm{h}^{-1}$ \\
\hline R15 & $16.773 \mathrm{~s}$ & $154.75 \mathrm{~km} \cdot \mathrm{h}^{-1}$ & $22.804 \mathrm{~s}$ & $149.86 \mathrm{~km} \cdot \mathrm{h}^{-1}$ \\
\hline
\end{tabular}

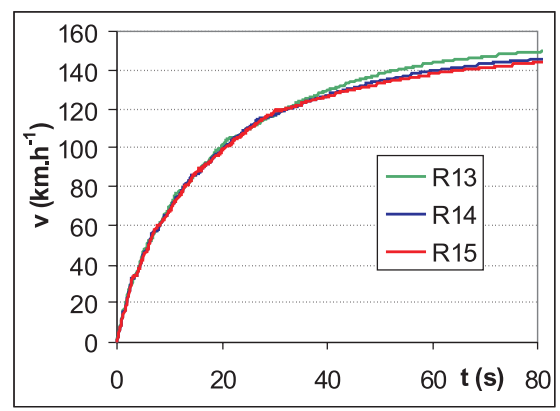

Fig. 7 Gear change at $4000 \mathrm{~min}^{-1}$

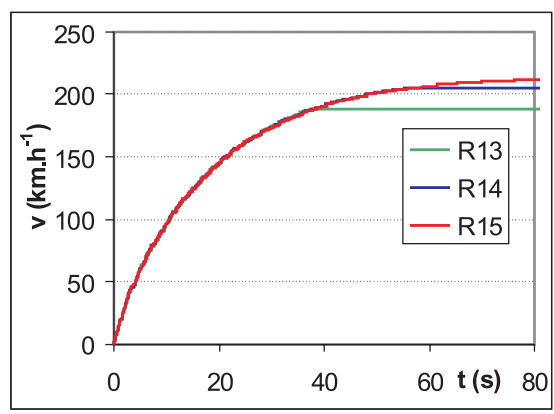

\section{Conclusion}

The results of analysis show that the parameters as the maximal vehicle velocity and the time of achieving $100 \mathrm{~km} . \mathrm{h}^{-1}$ velocity are not clearly equivalent to the wheel size (with respect to the chosen value of rotational speed during the gear changing and the time variances of the gear changing).

For example, as shown in the table 1, from the compared wheels R13, R14 and R15 in the case of the gear changing at $5500 \mathrm{rpm}$ $\left(\min ^{-1}\right)$, the maximal velocity is achieved by the wheels R14 and the maximal acceleration is achieved by the wheels R13. With the wheels R15 the value of the maximal vehicle speed is the lowest, which is due to a smaller traction force on the bigger driving wheel, 
in addition, the engine also operates at a little smaller rotational speed with an equivalent lower power. In the case of a gear changing at $4000 \mathrm{rpm}\left(\mathrm{min}^{-1}\right)$ the maximal speed of vehicle is achieved by the wheels R13 due to the highest traction force on the small driving wheels.
In spite of worse vehicles dynamic properties, the big wheels can be advantageous on the score of the lower fuel consumption the engine operates at a lower rotational speed (in the case of equal vehicle speed) and (also) the rolling resistance is smaller too.

\section{Reference:}

[1] ISTENÍK R., FITZ P.: The program DYNAST - solved examples from area of transport and handling machinery (in Slovak), EDIS, University of Žilina, ISBN 80-7100-829-X, Žilina, 2001.

[2] ISTENÍK, R., BARTA, D.: Simulation analysis of a type of engine on dynamical characteristics of an automobile (in Slovak), In: PERNER'S CONTACT 2003, Section 3, University Pardubice, DFJP, Pardubice, 2003, ISBN 80-7194-522-6.

[3] LABUDA, R.: Experimental results from the combustion engine electronic regulator research (in Slovak), Mechanical engineering in economy and industry 3/1999, Žilina, 1999, ISSN 1335-2938. 